\title{
Synthesis, Characterization and Application by HVOF of a WCCoCr/NiCr Nanocomposite as Protective Coating Against Erosive Wear
}

\author{
W.C. Giaglianonia, M.A. Cunha a , C.P. Bergmanna ${ }^{a}$ C. Fragassa ${ }^{b}$, A. Pavlovic ${ }^{b}$ \\ a Federal University of Rio Grande do Sul Department of Materials Engineering, Brazil, \\ ${ }^{\mathrm{b}}$ Department of Industrial Engineering, University of Bologna, viale Risorgimento, 2, Bologna, Italy.
}

Keywords:

WCCoCr

$\mathrm{NiCr}$

Nanocomposite

High energy milling

HVOF

Erosive wear

\section{Corresponding author:}

Waleska Campos Guaglianoni

Federal University of Rio Grande do Sul,

Osvaldo Aranha Avenue,

99 Porto Alegre-RS-Brazil.

E-mail: waleskaguaglianoni@yahoo.com.br

\begin{abstract}
A B S T R A C T
The scope of this work is to synthetize and characterize a WCCoCr/NiCr nanocomposite evaluating its application as protective coating against erosive wear when applied by High Velocity Oxygen Fuel (HVOF). The composite was formed by carbide of tungsten-cobalt-chrome (WCCoCr) processed by high energy milling and a metallic matrix of nickelchrome (NiCr). The milled material was added to the NiCr in the fraction of 5\%wt. The powders were investigated by X-ray diffraction and and scanning electron microscopy, analysing particle size distribution and surface area. The protective layers were deposited by HVOF and evaluated for their microhardness, microstructure, porosity, and erosive wear. Their microstructure showed lamellar character, with a low level of oxides and porosity between $0.5 \%$ and $1 \%$. The coating formed by $\mathrm{NiCr}$ and WCCoCr milled for 3 hours presented microhardness of $635 \mathrm{HV}$ and erosion rates $50 \%$ smaller than the commercial coating.
\end{abstract}

(C) 2018 Published by Faculty of Engineering

\section{INTRODUCTION}

Erosive wear affects numerous industries nowadays, such as oil and gas [1-2], power generation, mining, ground motion, metalworking, aerospace or automotive. Components failures may result in significant financial loss and environmental troubles [3]. Thus, many studies dealing with technical solutions, materials and wear-resistant coatings have been carried out in the recent years in order to increase components service life [4-9]. In the oil industry, in particular, the erosive wear is mainly caused by the presence of solid particles such as sand. The continuous impact of sand particles inside pipelines, valves and other equipment causes extensive damages. The worst-case scenario generally occurs where there is a co-presence of both erosion and oxidation, especially in the cases of higher temperatures. The corrosive degradation is accelerated by the erosive mechanism attributed to the sand impingement, resulting in a synergistic effect known as 'erosion-corrosion' [10]. Tungsten-cobalt carbide (WCCo) and nickel-chrome carbide-based ( $\mathrm{NiCr}$ ) coatings are 
widely used in the way to improve the wear resistance [11-17]. These ceramic-metallic materials (cermets) consist of ceramic particles embedded in a metal matrix. The particles in ceramic offer a high erosion resistance. The metallic matrix makes the coating more ductile than a pure ceramic coating [18]. NiCr systems stand out since they can be utilized at higher temperature under wear and corrosion [7].

Also, they are considered to be an excellent replacement to electrolytic hard chrome in the realisation of thick and wear-resistant coatings $[19,20]$.

WCCo and NiCr cermets can be in general deposited by thermal spray processes such as detonation spray, and high-velocity oxygen fuel spray (HVOF). The high particle velocity and the low flame temperatures by HVOF method produce coatings with the following properties: high densification, strong adhesion between coating and substrate, low residual stress, low porosity (typically $<1 \%$ ) and low chemical decomposition of WC particles [7,21,22].

Many studies about WCCo coatings use conventional commercial spray powders material [14,23-25]. The utilization of nanostructured materials may increase the performance of these coatings. The physical and mechanical properties of these materials are better because of the reduced grain size and of the high volumetric fraction of atoms in the grain boundary [26]. Refinement of grain sizes down to nanometer range can be achieved by mechanical alloying (MA) [27]. Nanostructured powders produced by MA possess physical and mechanical properties different from those of materials prepared by conventional techniques [28]. MA is a high-energy ball milling technique used to produce a variety of materials, such as borides, carbides, nitrides, oxides and nanocomposites [29-33]. Many studies have been conducted about WCCo nanocomposites obtained by high energy ball milling [34-40].

This research investigates in details the process of synthesis of a WCCoCr/NiCr nanocomposite coatings, permitted by high energy milling technique, and evaluates the effects of its application by high velocity oxygen fuel (HVOF) spray technology in terms of protection against erosive wear.

\section{MATERIAL AND METHODS}

\subsection{Materials}

The carbide of tungsten-cobalt-chrome (WCCoCr) and nickel-chrome (NiCr) employed were produced by Sulzer Metco (Woka 3652 and Diamalloy 2001, respectively). Tables 1 and 2 show the chemical composition of the starting powders.

Table 1. Chemical composition of WCCoCr commercial powder.

\begin{tabular}{|c|c|}
\hline Element & Composition (\%) \\
\hline $\mathrm{W}$ & Balance \\
\hline $\mathrm{Co}$ & $8.5-11.5$ \\
\hline $\mathrm{Cr}$ & $3.4-4.6$ \\
\hline $\mathrm{C}$ & $4.8-5.6$ \\
\hline $\mathrm{Fe}$ & 0.2 \\
\hline
\end{tabular}

Table 2. Chemical composition of $\mathrm{NiCr}$ commercial powder.

\begin{tabular}{|c|c|}
\hline Element & Composition (\%) \\
\hline $\mathrm{Ni}$ & Balance \\
\hline $\mathrm{Cr}$ & 17 \\
\hline $\mathrm{B}$ & 3.5 \\
\hline $\mathrm{Si}$ & 4 \\
\hline $\mathrm{C}$ & 1 \\
\hline $\mathrm{Fe}$ & 4 \\
\hline
\end{tabular}
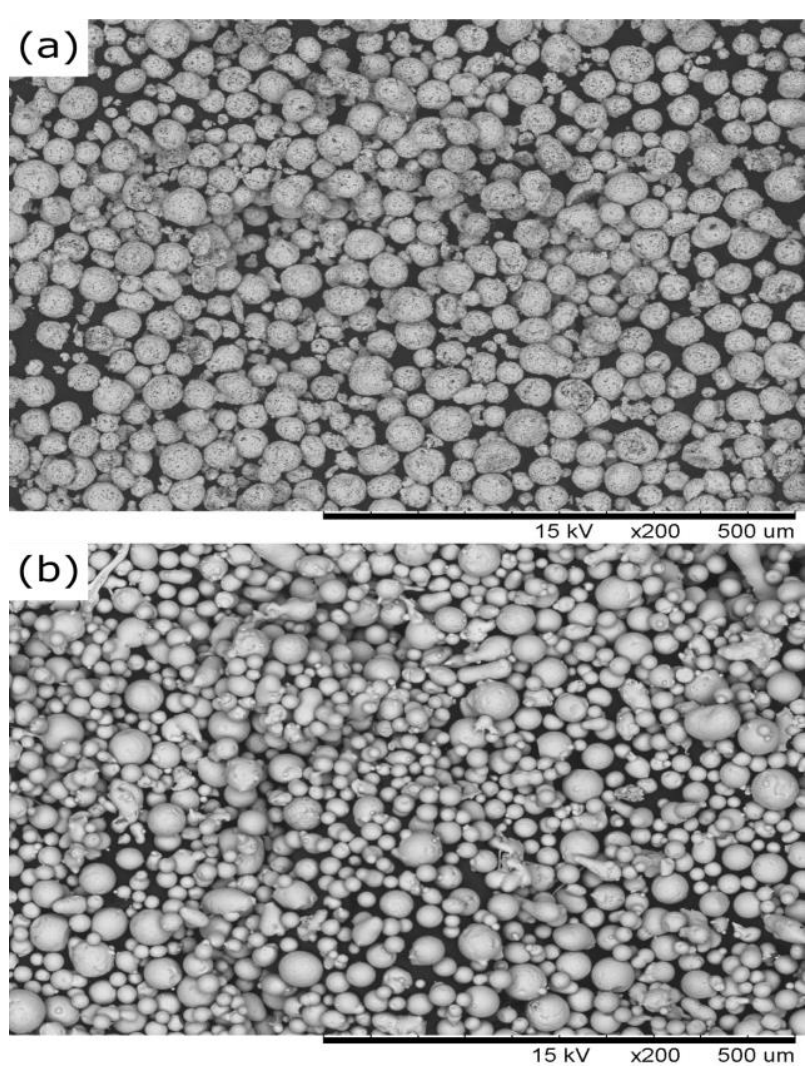

Fig. 1. (a) SEM images of WCCoCr and (b) $\mathrm{NiCr}$ particles as-received. 
Figures 1a-1b show the morphology of WCCoCr and $\mathrm{NiCr}$ as-received, respectively. Both materials display a spheroidal morphology, which is characteristic of the production process employed. WCCoCr was agglomerated and sintered, while the $\mathrm{NiCr}$ was gas-atomized.

\subsection{Synthesis of WCCoCr/NiCr nanocomposites}

The high energy ball milling of WCCoCr was carried out at room temperature, using a planetary ball mill (Pulverisette 6, Fritsch). A tempered steel grinding bowl and AISI 52100 steel balls, with $10 \mathrm{~mm}$ in diameter, were used. The milling was performed in ethanol medium, using a ball-to-powder ratio (BPR) of 1:1, a milling speed of $450 \mathrm{rpm}$ and three milling times (3, 6 and 12 hours). WCCoCr was added to $\mathrm{NiCr}$ in the amount of $5 \%$. The mixture was agglomerated and treated thermally (heating rate: $100{ }^{\circ} \mathrm{C} / \mathrm{min}$; dwell 1 : $3 \mathrm{~h}$ at $350{ }^{\circ} \mathrm{C}$; dwell 2 : $6 \mathrm{~h}$ at $850^{\circ} \mathrm{C}$ ).

\subsection{Nanocomposites characterization}

Powders obtained by high energy ball milling and the alloys formed by the mixture of WCCoCr and $\mathrm{NiCr}$ were characterized by X-ray diffraction (XRD), particle size analysis, surface area, and scanning electron microscopy (SEM).

Table 3. XRD analysis parameters.

\begin{tabular}{|c|c|c|}
\hline Parameter & Phase analysis & Crystallite size \\
\hline$\Delta 2 \theta$ & $25^{\circ}-105^{\circ}$ & $34^{\circ}-38^{\circ}$ \\
\hline Step & 0.05 & 0.04 \\
\hline Time per step (s) & 1 & 4 \\
\hline Cracks & $1 / 2$ & $1 / 4$ \\
\hline
\end{tabular}

The crystalline phases and crystallite sizes were determined using X-ray powder diffraction (Phillips diffractometer, X'Pert MPD model). The diffractometer has a graphite monochromator, $\mathrm{Cu}-\mathrm{K} \alpha$ radiation $(\lambda=1.5406)$, and a fixed anode operated at $40 \mathrm{kV}$ and $40 \mathrm{~mA}$. Table 3 shows the selected parameters for the phase analysis and determination of the crystallite size. Crystallite size was calculated by measuring the Bragg peak width at half maximum intensity and using the Scherrer's equation (1):

$$
\beta=\frac{0.9 \cdot \lambda}{D \cdot \cos \theta}
$$

$\beta$ is the pure broadening of the diffraction peak measured at half maximum intensity,

$\lambda$ is the wavelength of the $X$-ray radiation used, $\theta$ is the Bragg angle [41].

The average grain diameter was measured with a CILAS 1180 particle size analyser (CILAS). The surface area was determined by the Branauer, Emmett and Teller method [42], using an Autosorb Quantachrome (model NOVA 1000) apparatus. The microstructure of the milled WCCo powders was observed by a scanning electron microscope (SEM, Hitachi-TM 3000).

\subsection{Thermal spray coating deposition}

The coatings were deposited using a TAFA JP5000 HVOF spray system (PRAXAIR SURFACE TECHNOLOGIES Inc) with process parameters listed in Table 4. A substrate of AISI 310 stainless steel with cylindrical format $(30 \mathrm{~mm} \mathrm{X}$ $6 \mathrm{~mm}$ ) was used. The substrates were gritblasted with Al2O3 before spraying to provide a roughened surface. No thermal treatment was performed on the substrates.

Table 4. HVOF process parameters.

\begin{tabular}{|c|c|}
\hline Parameters & Values \\
\hline Kerosene flow rate $(\mathrm{l} / \mathrm{min})$ & 0.385 \\
\hline Oxygen flow rate $\left(\mathrm{m}^{3} / \mathrm{h}\right)$ & 58.2 \\
\hline Feed rate $\left(\mathrm{m}^{3} / \mathrm{h}\right)$ & 0.3 \\
\hline Spray distance $(\mathrm{mm})$ & $300 \mathrm{~mm}$ \\
\hline
\end{tabular}

\subsection{Coating characterization}

Vickers microhardness tests were performed using a Buehler Micromet 2000 with a load of 3 $\mathrm{N}$. Indents were placed in matrix and carbides areas. Microstructural characterization of the coatings was carried out by an Olympus BXS1M microscope. Porosity analysis was done using image analysis software (Image J), after ASTM E2109-01 [43].

The equipment used in erosive wear tests is based on [44]. The details of the experimental set-up are presented in [45-46]. Electromelted alumina was used as erodent. Tests were performed at room temperature, with incidence angles of $30^{\circ}$ and $90^{\circ}$. Erosion rate of the coatings were measured by weight loss.

where:

$\mathrm{D}$ is the crystallite size, 


\section{RESULTS AND DISCUSSION}

\subsection{WCCnCr processed by high energy ball milling}

Figure 2a shows the XRD diffractograms of the raw material and the ball-milled powders. The presence of the WC (JCPDS 00-051-0939) and Co (JCPDS 00-015-0806) phases can be identified. Figure $2 b$ shows the two first diffraction peaks shown in Fig. 2a in detail. After ball milling, the diffraction peaks broaden, as a result of the reduction in crystallite size and the enhancement of its internal strain $[27,47]$. This behaviour was observed by [39] for short milling times, and by $[38,48-50]$ for long milling times.
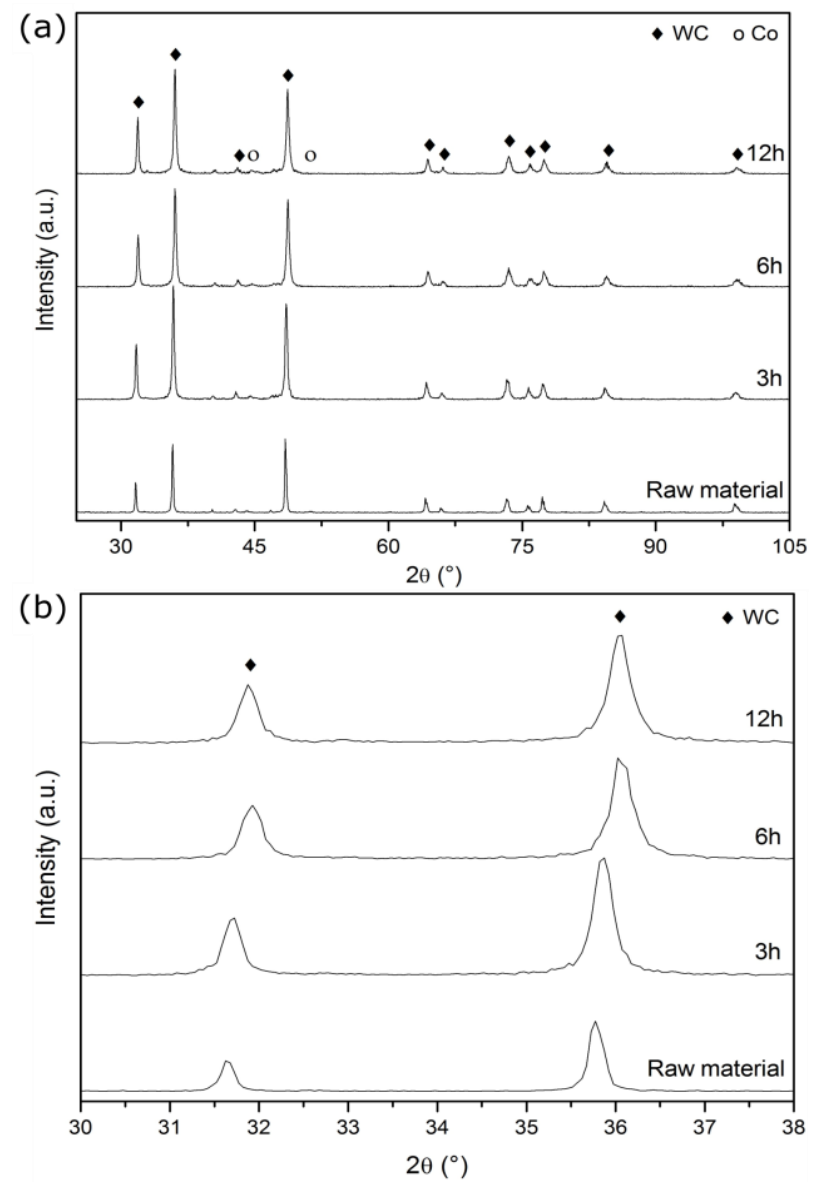

Fig. 2. (a) X-ray patterns of WCCoCr particles asreceived and after ball milling, (b) Detailed X-ray patterns of the first two diffraction peaks of WCCoCr particles as-received and after ball milling.

The crystallite size development as function of the milling time is shown in Fig. 3. An important reduction of crystallite size for the first hours of milling can be observed. The crystallite size decreases with the enhancement of the milling time, and achieves a relatively constant value.
Crystallite sizes are smaller than $30 \mathrm{~nm}$. Enayati [38] and Xueming [48] obtained crystallite sizes of nearly $10 \mathrm{~nm}$. This difference may be explained by the higher BPR's (10:1 and 30:1, respectively) used by these authors. On the other hand, [40] obtained a large crystallite size $(45 \mathrm{~nm})$ using a milling time of 25 hours and a milling speed of $130 \mathrm{rpm}$.

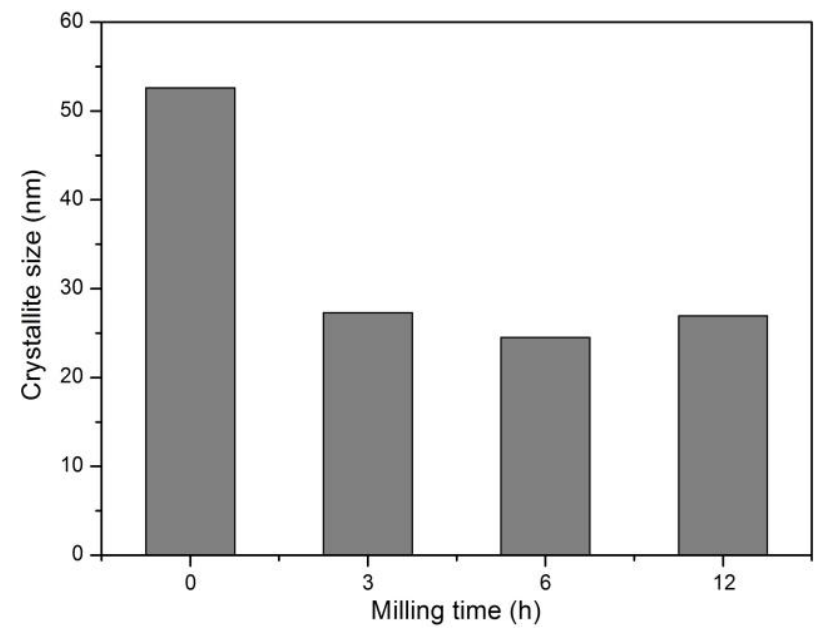

Fig. 3. Crystallite size of WCCoCr as function of milling time.

Figure 4 displays the D10, D50 and D90 variation as function of the milling time. A significant reduction of the particle size after 3 and $6 \mathrm{~h}$ of milling can be observed, due to fracture of the coarse fraction. D90 increases for the milling time of $12 \mathrm{~h}$, probably due to the overlap and the cold welding of small fragments [27].

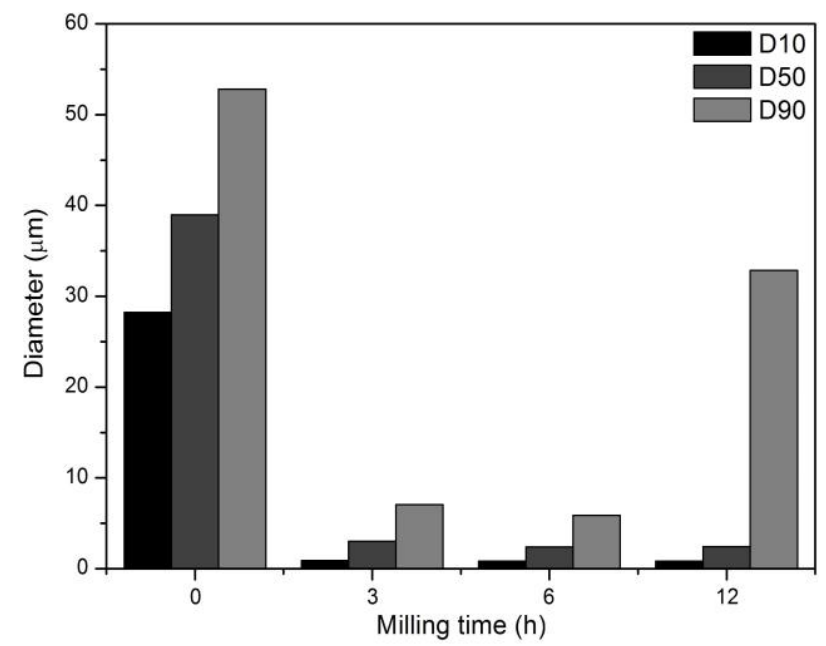

Fig. 4. D10, D50 and D90 of WCCoCr as function of milling time.

The surface areas of the WCCoCr processed as function of the milling time are shown in Fig. 5. The highest surface area was observed for the 
sample milled for $6 \mathrm{~h}$, which has the smallest crystallite size (Fig. 3). All samples had a small change in the surface area compared to the material without milling (with $\mathrm{SA}=5.451 \mathrm{~m}^{2} / \mathrm{g}$ ). This behaviour was observed by [37] during preparation of a WC-12Co alloy by mixing WC with Co in a planetary mill. The surface area of the material obtained by the researchers increased with the milling time. After a milling time of $25 \mathrm{~h}$, the surface area achieved the value of $4.687 \mathrm{~m}^{2} / \mathrm{g}$.

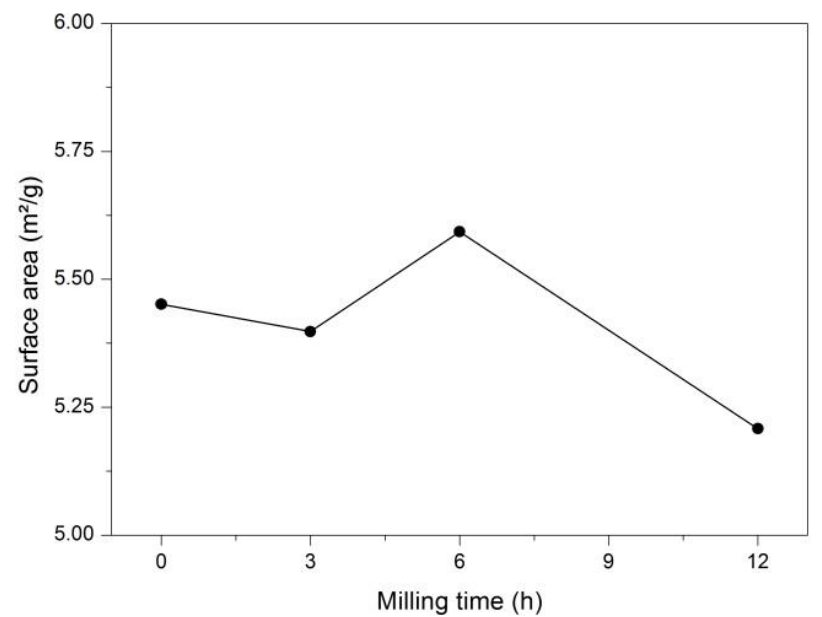

Fig. 5. Surface area of WCCoCr particles as function of milling time.
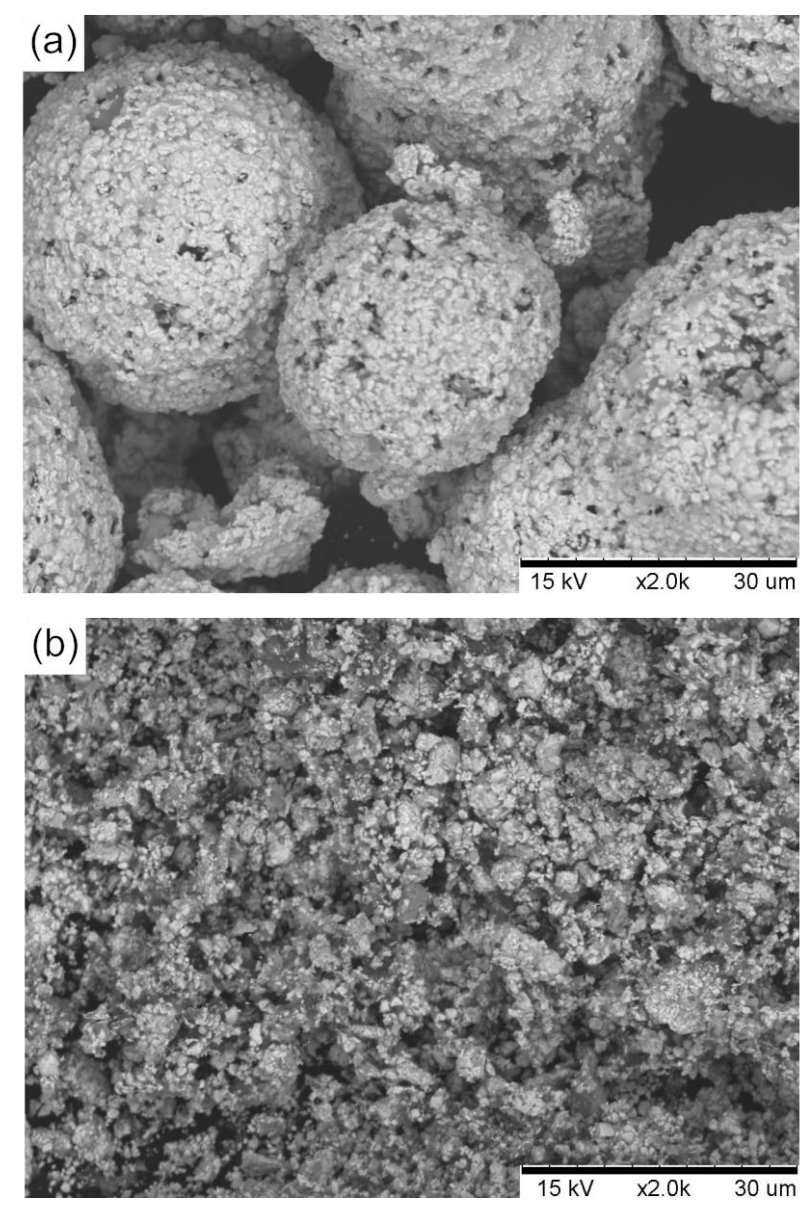
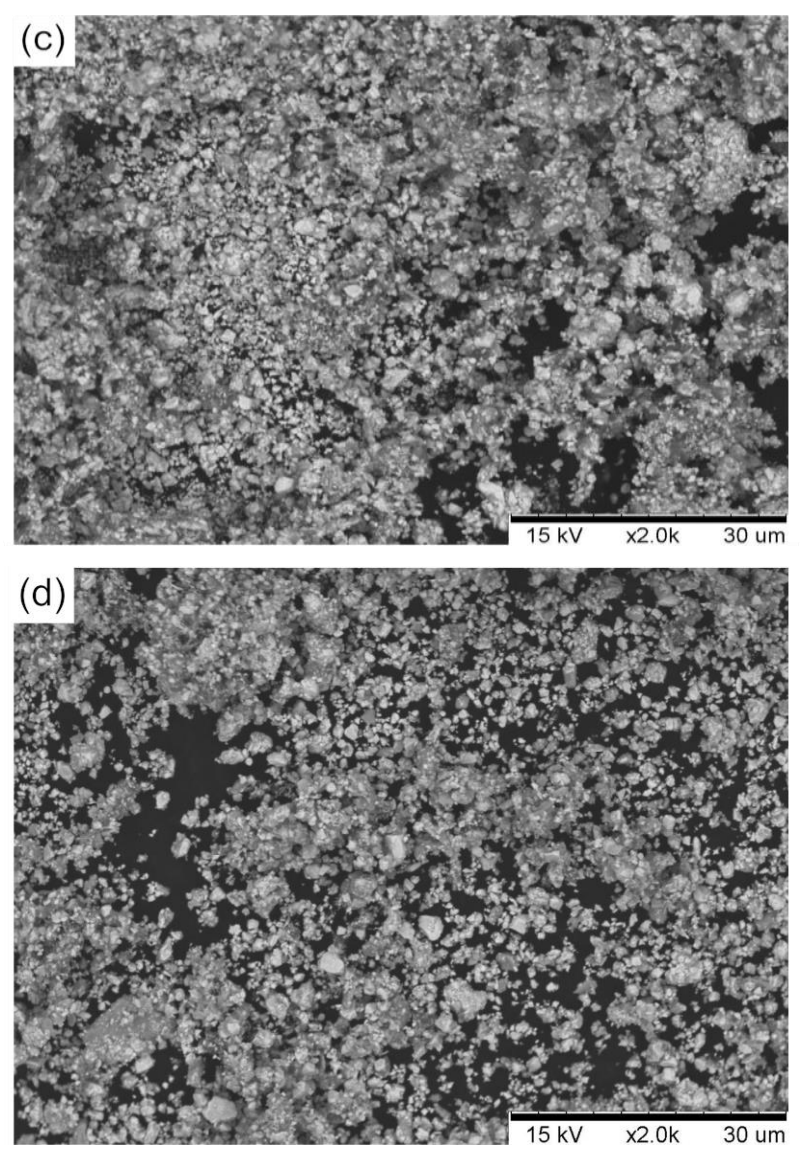

Fig. 6. SEM images of WCCoCr as raw material (a), and as milled powder by $3 \mathrm{~h} \mathrm{(b),} 6 \mathrm{~h}$ (c) and $12 \mathrm{~h}$ (d).

Commercial material particles (Fig. 6a) were nearly spherical, typical of the production process used (agglomeration and sintering). Figures 6b-6d show the material after 3,6 and $12 \mathrm{~h}$ of milling, respectively. After ball milling, the particles were fragmented into fine powder. The WCCoCr particles lost their starting morphology and had their size significantly reduced in the first hours of milling. Significant modifications in the powders morphology were also detected by $[33,38,51]$. WCCoCr milled for $6 \mathrm{~h}$ (Fig. 6c) showed particles smaller than the sample milled for $12 \mathrm{~h}$ (Fig. 6d). This is also in accordance with the average value measured for the grain diameter.

\subsection{WCCoCr-NICr nanocomposites}

Figure 7 shows the SEM images and the particle median size (D50) of the alloys formed by the mixture of $5 \%$ of WCCoCr and NiCr. All samples presented spherical and larger particles of $\mathrm{NiCr}$, and smaller particles of WCCoCr. The samples with milled WCCoCr presented particles smaller than the samples with raw material. All samples showed particle median size appropriate for utilisation in HVOF spray systems. 

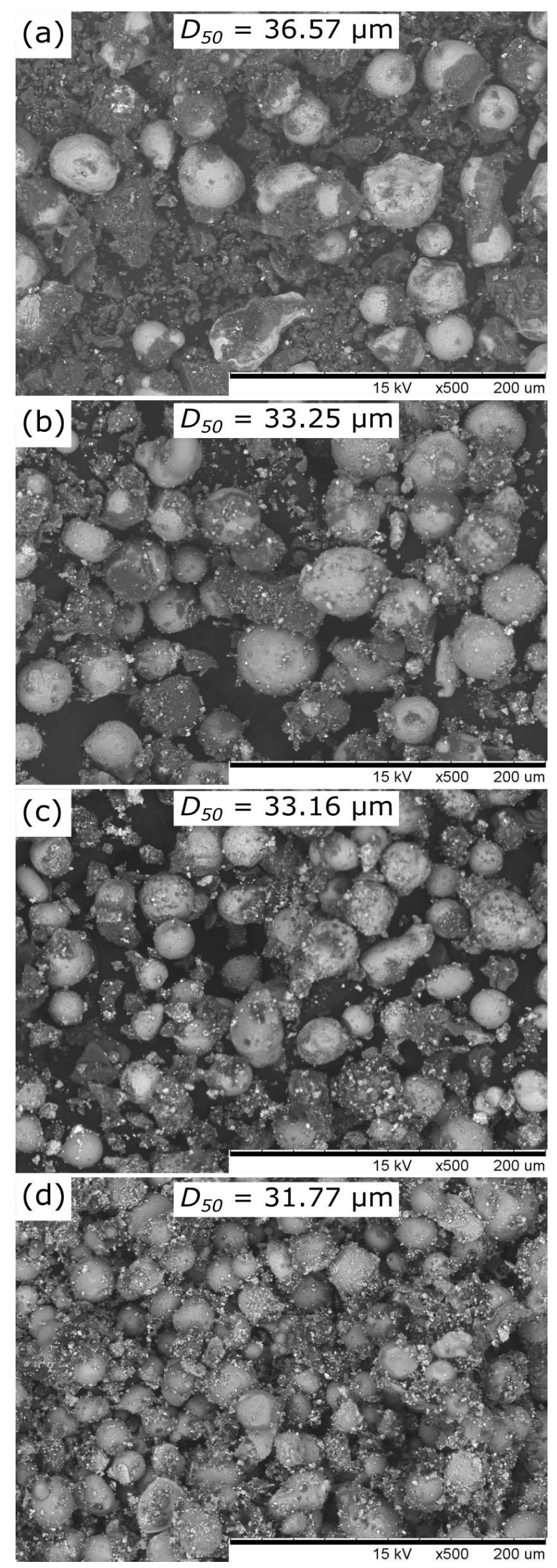

Fig. 7. SEM images of the alloys formed by the mixture of $5 \%$ of WCCoCr and NiCr. WCCoCr as raw material (a), and as milled powder by $3 \mathrm{~h} \mathrm{(b),} 6 \mathrm{~h}$ (c) and $12 \mathrm{~h}(\mathrm{~d})$.

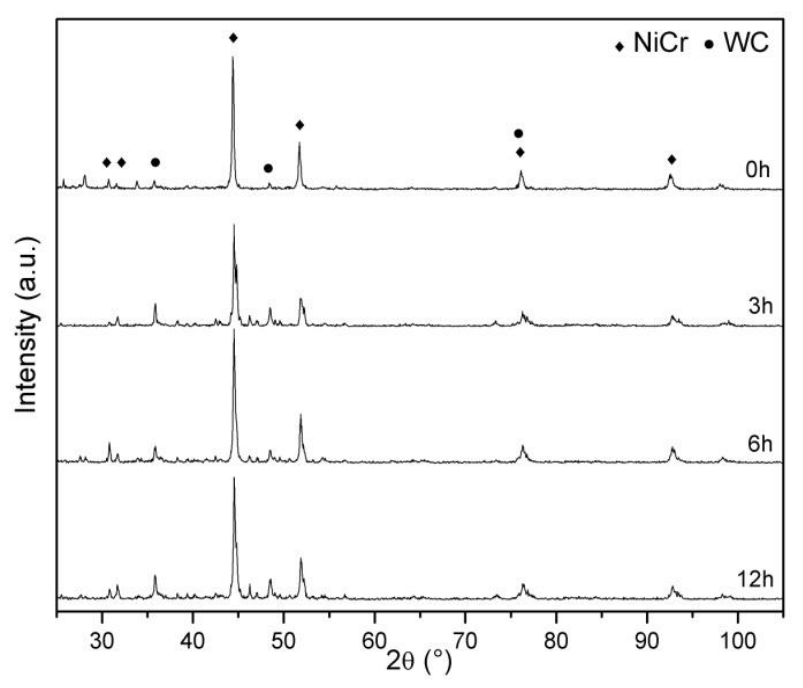

Figure 8: X-ray patterns of the alloys formed by the mixture of WCCoCr and NiCr.

Figure 8 shows the XRD diffractograms of the alloys formed by the mixture of $5 \%$ of WCCoCr and NiCr. The presence of the tungsten carbide (WC) and nickel-chrome (Cr1.12Ni2.88) phases can be identified.

\subsection{WCCoCr-NICr Coating}

Figure 9 shows the microstructures of the layers obtained by thermal spray of the WCCoCr-NiCr alloys. The microstructures presented low quantity of oxides. The coating obtained with asreceived WCCoCr (Fig. 9a) did not show lamellas. Other coatings' microstructure (Figs. 9b-9d) showed a more evident lamellar character.
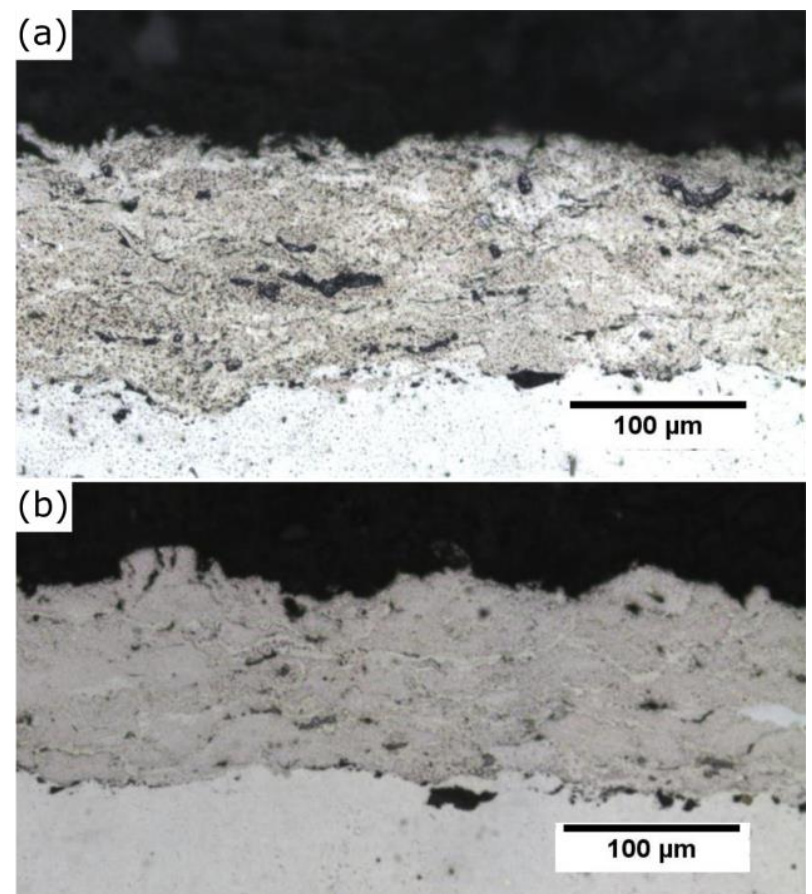

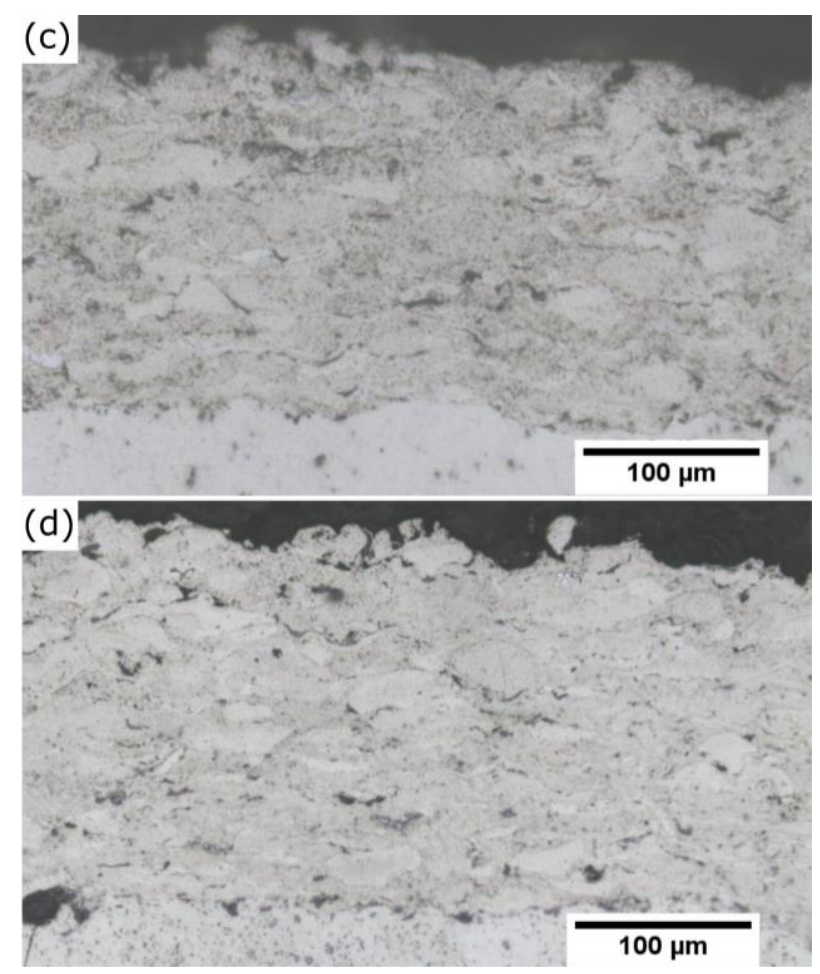

Fig. 9. Coating microstructure of WCCoCr-NiCr alloy with $5 \%$ of WCCoCr raw material (a) and milled by 3 $\mathrm{h}(\mathrm{b}), 6 \mathrm{~h}$ (c) and $12 \mathrm{~h}(\mathrm{~d})$.

After analysis of three samples of each coating, the average porosity was quantified between 0.5 and $1 \%$, according to [43]. Berger et al. [52] obtained porosity between 0.7 and $1.8 \%$ for a WC-NiCr. Thakur et al. [13] compared two WCCo-Cr coatings: the first with carbide size between 200 and $500 \mathrm{~nm}$, and the second with $100 \mathrm{~nm}$. The porosities obtained were $0.75 \%$ and $0.57 \%$, respectively.

Table 5. Microhardness coatings.

\begin{tabular}{|c|c|c|}
\hline Coating & $\begin{array}{c}\text { Microhardness } \\
\text { Matrix (HV) }\end{array}$ & $\begin{array}{c}\text { Microhardness } \\
\text { Carbides (HV) }\end{array}$ \\
\hline raw material & 424 & 876 \\
\hline $3 \mathrm{~h}$ & 404 & 635 \\
\hline $6 \mathrm{~h}$ & 406 & 823 \\
\hline $12 \mathrm{~h}$ & 406 & 598 \\
\hline
\end{tabular}

Microhardness tests were implemented in the coatings matrix and in the areas with probable presence of carbides. Table 5 shows microhardness values for both areas. The identification of areas with higher microhardness, possibly containing carbides, was more evident for the coatings with $5 \%$ of WCCoCr raw material and $5 \%$ of WCCoCr milled for 6 hours. The carbides were dispersed in a NiCr matrix of the coatings $5 \%$ of WCCoCr milled for $3 \mathrm{~h}$ and $12 \mathrm{~h}$. Figure 10a shows an indentation in the matrix area for the coating $5 \%$ of WCCoCr $3 \mathrm{~h}$. The average microhardness (404 HV) indicates that this area is more ductile. Figure $10 \mathrm{~b}$ shows an indentation in the carbides area for the coating 5 $\%$ of WCCoCr $6 \mathrm{~h}$. This coating presented microhardness of 823 HV. Murthy and Venkataraman [19] obtained a similar result (836 $\pm 30 \mathrm{HV}$ ) for a WCCoCr coating. Berger et al. [52] reported a microhardness of $1012 \pm 90 \mathrm{HV}$ for a WC-NiCr coating.
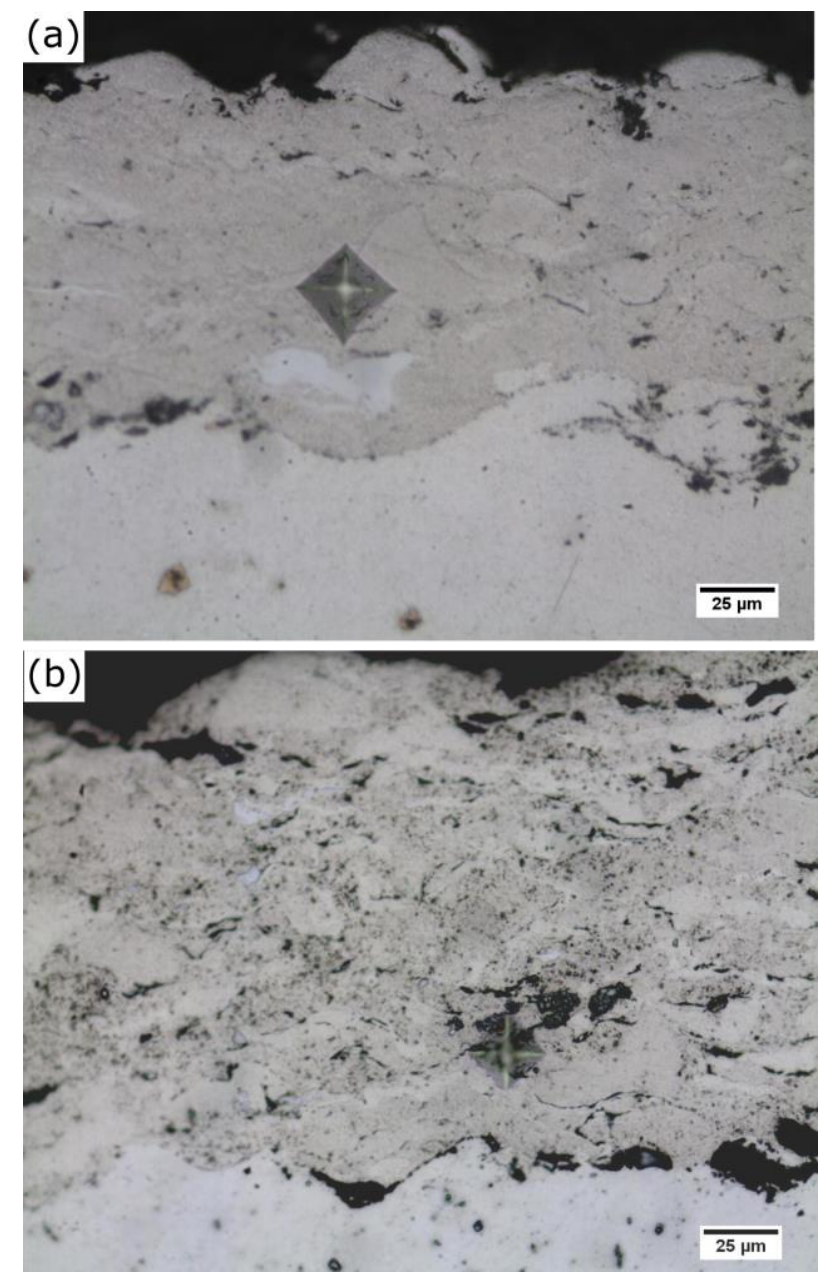

Fig. 10. (a) Indentation in the matrix area for the coating of WCCoCr-NiCr with $5 \%$ of WCCoCr milled for $3 \mathrm{~h}$. (b) Indentation in the carbide area for the WCCoCr-NiCr wih $5 \%$ of WCCoCr milled for $6 \mathrm{~h}$.

Figure 11 shows the erosion rate, in weight loss, for the WCCoCr-NiCr coatings. In the tests performed with an attack angle of $30^{\circ}$, the coatings obtained with nanostructured WCCoCr had smaller erosive wear than the coating obtained with WCCoCr raw material. The coatings formed by WCCoCr milled for 3 and 12 $\mathrm{h}$ showed similar performance and erosion rate $50 \%$ smaller than the commercial coating. In the tests performed with an attack angle of $90^{\circ}$, 
the erosion rate increased for milling times higher than 6 hours.

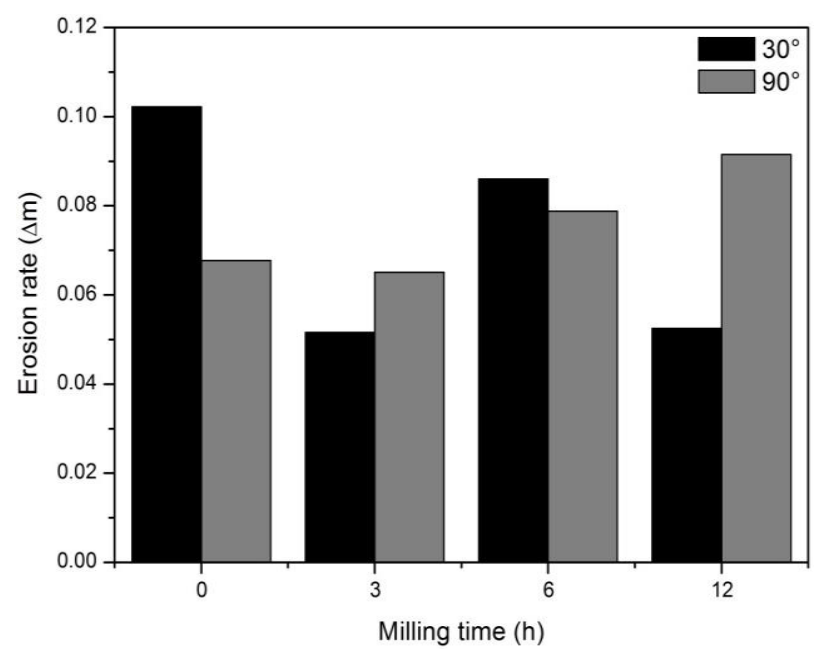

Fig. 11. Erosion rate of the wccocr-nicr coating.

The protection obtained with WCCoCr milled for $3 \mathrm{~h}$ showed erosion rate lower than the raw material. The coatings $5 \%$ WCCoCr commercial and $6 \mathrm{~h}$ presented higher erosive wear in $30^{\circ}$ than in $90^{\circ}$, indicating behavior of ductile material. On the other hand, the coatings $5 \%$ WCCoCr 3 and $12 \mathrm{~h}$ showed higher erosive wear in $90^{\circ}$, indicating a brittle behavior [53-54].

\section{CONCLUSIONS}

According to the results presented, it can be concluded that:

- High energy ball milling was effective to refine the microstructure of WCCoCr powders to a nanometer scale size. The crystallite size was smaller than $30 \mathrm{~nm}$ after 3 hours of milling. The WCCoCr particles lost their starting morphology and had their size significantly reduced in the first hours of milling. For longer milling times, occurred the overlap and the cold welding of small fragments, increasing the mean diameter.

- The coatings showed lamellar character, with low level of oxides and porosity inside the range of $0.5 \%$ and $1 \%$.

- The coatings obtained with $5 \%$ of WCCoCr milled for 3 and $12 \mathrm{~h}$ presented carbides more dispersed in the NiCr matrix. On the other side, the carbides were observed in concentrated areas in the coatings with $5 \%$ of WCCoCr raw material and milled for $6 \mathrm{~h}$.
- The erosive wear was higher for the attack angle of $30^{\circ}$ for the coatings with $5 \%$ of WCCoCr raw material and milled for 6 h. For this attack angle, the erosive wear is higher for the materials that show ductile behaviour.

- The coating with $5 \%$ of WCCoCr milled for 3 h presented microhardness of $635 \mathrm{HV}$ with an erosion rate of $50 \%$, smaller than the commercial coating for the attack angle of $30^{\circ}$.

\section{Acknowledgement}

The financial support of IBP (Brazilian Institute of Petroleum) is gratefully acknowledged.

\section{REFERENCES}

[1] M. Parsi, K. Najmi, F. Najafifard, S. Hassani, B.S., McLaury, S.A. Shirazi, A comprehensive review of solid particle erosion modeling for oil and gas wells and pipelines applications, Journal of Natural Gas Science and Engineering, vol. 21, pp. 850-873, 2014, doi: 10.1016/j.jngse.2014.10.001

[2] R. Zhang, H. Liu, C. Zhao, A probability model for solid particle erosion in a straight pipe, Wear, vol. 308, iss. 1-2, pp. 1-9, 2013, doi: 10.1016/j.wear.2013.09.011

[3] C. Fragassa, M. Ippoliti, Failure Mode Effects and Criticality Analysis (FMECA) as a quality tool to plan improvements in Ultrasonic Mould Cleaning Systems, International Journal for Quality Research, vol. 10 , no. 4 , pp. 847-870, 2016, doi: 10.18421/IJQR10.04-14

[4] R.G. Ripeanu, V. Ispas, D. Ispas, Review above Applying Active Anode Protection at Some Dynamic Petroleum Equipment's in Order to Reduce Wear, FME Transactions, vol. 43, no. 3, pp. 199, 2015.

[5] C. Fragassa, G. Minak, A. Pavlovic, Tribological aspects of cast iron investigated via fracture toughness, Tribology in Industry, vol. 38, no. 1, pp 1-10, 2016.

[6] H. Oflaz, Z. Parlar, V. Temiz, The Investigation of Friction and Wear Characteristic of Cast Iron against Manganese Phosphate Coated and Austempered Compressor Crankshaft, FME Transactions, vol. 43, no. 3, pp. 187, 2015.

[7] C.P. Bergmann, J. Vicenzi, Protection against erosive wear using thermal sprayed cermet: a review, Berlin, Heidelberg: Springer, 2011. 
[8] C. Fragassa, A. Pavlovic, I. Zivkovic, The accelerated aging effect of salt water on lignocellulosic fibre reinforced composites, Tribology in Industry, vol 40, no. 1, pp. 1-9, 2018, doi: 10.24874/ti.2018.40.01.01

[9] J. Vite-Torres, M. Vite-Torres, R.A. Osorio, J.E. Reyes-Astivia, Tribological and corrosion properties of nickel coatings on carbon steel, FME Transactions, vol. 43, no. 3, pp. 206-210, 2015.

[10] X. Hu, R. Barker, A. Neville, A. Gnanavelu, Case study on erosion-corrosion degradation of pipework located on an offshore oil and gas facility, Wear, vol. 271, no. 9-10, pp. 1295-1301, 2011, doi: 10.1016/j.wear.2011.01.036

[11] W. Zórawski, S. Skrzypek, J. Trpčevska, Tribological properties of hypersonically sprayed carbide coatings, FME Transactions, vol. 36, no. 2, pp. 81-86, 2008.

[12] R.J.K. Wood, Tribology of thermal sprayed WC-Co coatings, International Journal of Refractory Metals and Hard Materials, vol. 28, iss. 1, pp. 8294, 2010, doi: 10.1016/j.ijrmhm.2009.07.011

[13] L. Thakur, N. Arora, R. Jayaganthan, R. Sood, An investigation on erosion behavior of $\mathrm{HVOF}$ sprayed WC-CoCr coatings, Applied Surface Science, vol. 258, iss. 3, pp. 1225-1234, 2011, doi: 10.1016/j.apsusc.2011.09.079

[14] M. Xie, S. Zhang, M. Li, Comparative investigation on HVOF sprayed carbide-based coatings, Applied Surface Science, vol. 273, pp. 799-805, 2013, doi: 10.1016/j.apsusc.2013.03.010

[15] N. Ma, L. Guo, Z. Cheng, H. Wu, F. Ye, K. Zhang, Improvement on mechanical properties and wear resistance of HVOF sprayed WC-12Co coatings by optimizing feedstock structure, Applied Surface Science, vol. 320, pp. 364-371, 2014, doi: 10.1016/j.apsusc.2014.09.081

[16] Z. Geng, S. Li, S., D.L. Duan, Y. Liu, Wear behaviour of WC-Co HVOF coatings at different temperatures in air and argon, Wear, vol. 330-331, pp. 348-353, 2015, doi: 10.1016/j.wear.2015.01.035

[17] V. Matikainen, G. Bolelli, H. Koivuluoto, P. Sassatelli, L. Lusvarghi, P. Vuoristo, Sliding wear behaviour of HVOF and HVAF sprayed Cr3C2based coatings, Wear, vol. 388-389, pp. 54-71, 2017, doi: 10.1016/j.wear.2017.04.001

[18] P.L. Menezes, S.P. Ingole, M. Nosonovsky, S.V. Kailas, M.R. Lovell, Tribology for scientists and engineers, New York: Springer, 2013.

[19] J.K.N. Murthy, B. Venkataraman, Abrasive wear behaviour of $\mathrm{WC}-\mathrm{CoCr}$ and $\mathrm{Cr} 3 \mathrm{C} 2-20(\mathrm{NiCr})$ deposited by HVOF and detonation spray processes, Surface and Coatings Technology, vol.
200, iss. 8, pp. 2642-2652, 2006, doi: 10.1016/j.surfcoat.2004.10.136

[20] D. Toma, W. Brandl, G. Marginean, Wear and corrosion behaviour of thermally sprayed cermet coatings, Surface and Coatings Technology, vol. 138, iss. 2-3, pp. 149-158, 2001, doi: 10.1016/S0257-8972(00)01141-5

[21] M.M. El Rayes, H.S. Abdo, K.A. Khalil, Erosion Corrosion of Cermet Coating, International journal of electrochemical science, vol. 8, iss. 1, pp. 1117-1137, 2013.

[22] M.A. González, E. Rodríguez, E. Mojardín, O. Jiménez, H. Guillen, J. Ibarra, Study of the erosive wear behaviour of cryogenically and tempered $\mathrm{WC}-\mathrm{CoCr}$ coating deposited by HVOF, Wear, vol. 376-377, pp. 595-607, 2017, doi: 10.1016/j.wear.2016.12.061

[23] R. Schwetzke, H. Kreye, Microstructure and properties of tungsten carbide coatings sprayed with various High Velocity Oxygen Fuel spray systems, Journal of Thermal Spray Technology, vol. 8, iss. 3, pp. 433-439, 1999, doi: $10.1361 / 105996399770350395$

[24] P. Chivavibul, M. Watanabe, S. Kuroda, K. Shinoda, Effects of carbide size and Co content on the microstructure and mechanical properties of HVOFsprayed WC-Co coatings, Surface and Coatings Technology, vol. 202, iss. 3, pp. 509-521, 2007, doi: 10.1016/j.surfcoat.2007.06.026

[25] M. Jafari, M.H. Enayati, M. Salehi, S.M. Nahvi, C.G. Park, Comparison between oxidation kinetics of HVOF sprayed $W C-12 C o$ and $W C-10 C o-4 C r$ coatings, International Journal of Refractory Metals and Hard Materials, vol. 41, pp. 78-84, 2013, doi: 10.1016/j.ijrmhm.2013.02.006

[26] A.S. Edelstein, R.C. Cammaratra, Nanomaterials: synthesis, properties and applications, New York: CRC press, 1998.

[27] C. Suryanarayana, Mechanical alloying and milling, Progress in Materials Science, vol. 46, iss. $1-2$, pp. 1-184, 2001, doi: 10.1016/S00796425(99)00010-9

[28] L. Lü, M.O. Lai, Mechanical alloying, Springer, 2013.

[29] P. Matteazzi, G.L. Caer, Synthesis of nanocrystalline alumina-metal composites by room-temperature ball-milling of metal oxides and Aluminum, Journal of the American Ceramic Society, vol. 75 , iss. 10, pp. 2749-2755, 1992, doi: 10.1111/j.1151-2916.1992.tb05499.x

[30] C. Suryanarayana, Synthesis of nanocomposites by mechanical alloying, Journal of Alloys and Compounds, vol. 509, pp. S229-S234, 2011, doi: 10.1016/j.jallcom.2010.09.063 
[31] C. Suryanarayana, Mechanical Alloying and Milling, New York: CRC Press, 2004.

[32] C. Suryanarayana, N. Al-Aqeelib, Mechanically alloyed nanocomposites, Progress in Materials Science, vol. 58, iss. 4, pp. 383-502, 2013, doi: 10.1016/j.pmatsci.2012.10.001

[33] W.C. Guaglianoni, A.P. Garcia, T.M. Basegio, R. Felisberto, C.P. Bergmann, Influence of Milling parameters in the morphology of nanostructured CrC-30wt\% NiCr, Tecno-Lógica, vol. 21, no. 1, p. 3740, 2017, doi: 10.17058/tecnolog.v21i1.8249

[34] M.S. El-Eskandaranya, A.A. Mahdaya, H.A. Ahmedb, A.H. Amera, Synthesis and characterizations of ball-milled nanocrystalline WC and nanocomposite WC-Co powders and subsequent consolidations, Journal of Alloys and Compounds, vol. 312, iss. 1-2, pp. 315-325, 2000, doi: 10.1016/S0925-8388(00)01155-5

[35] F.L. Zhang, M. Zhu, C.Y. Wang, Parameters optimization in the planetary ball milling of nanostructured tungsten carbide/cobalt powder, International Journal of Refractory Metals and Hard Materials, vol. 26, iss. 4, pp. 329-333, 2008, doi: 10.1016/j.ijrmhm.2007.08.005

[36] S.A. Hewitt, K.A. Kibble, Effects of ball milling time on the synthesis and consolidation of nanostructured WC-Co composites, International Journal of Refractory Metals and Hard Materials vol. 27, iss. 6, pp. 937-948, 2009, doi: 10.1016/j.ijrmhm.2009.05.006

[37] M. Mahmoodan, H. Aliakbarzadeh, R. Gholamipour, Microstructural and mechanical characterization of high energy ball milled and sintered WC-10 wt\%Co-xTaCnano powders, International Journal of Refractory Metals and Hard Materials, vol. 27, iss. 4, pp. 801-805, 2009, doi: 10.1016/j.ijrmhm.2009.02.001

[38] M.H. Enayati, G.R. Aryanpour, A. Ebnonnasir, Production of nanostructured WC-Co powder by ball milling, International Journal of Refractory Metals and Hard Materials, vol. 27, iss. 1, pp. 159163, 2009, doi: 10.1016/j.ijrmhm.2008.06.005

[39] R.M. Raihanuzzaman, T.S. Jeong, R. Ghomashchi, Z. Xie, S.J. Hong, Characterization of short-duration high-energy ball milled WC-Co powders and subsequent consolidations, Journal of Alloys and Compounds, vol. 615, pp. S564-S568, 2014, doi: 10.1016/j.jallcom.2013.12.104

[40] K. Mandel, L. Krüger, C. Schimpf, Particle properties of submicron-sized WC-12Co processed by planetary ball milling, International Journal of Refractory Metals and Hard Materials, vol. 42, pp. 200-204, 2014, doi: 10.1016/j.ijrmhm.2013.09.006
[41] B.D. Cullity, Elements of X-ray Diffraction, Addison-Wesley, 2001.

[42] S. Brunauer, P.H. Emmett, E. Teller, Adsorption of gases in multimolecular layers, Journal of the American Chemical Society, vol. 60, no. 2, pp. 309-319, 1938, doi: 10.1021/ja01269a023

[43] ASTM E2109-01, Standard Test Methods for Determining Area Percentage Porosity in Thermal Sprayed Coatings, Annual Book of ASTM Standards, 2007.

[44] ASTM G76-13, Standard Test Method for Conducting Erosion Tests by Solid Particle Impingement Using Gas Jets, Annual Book of ASTM Standards, 2013.

[45] C.M. Marques, Relação entre microestrutura $e$ desgaste erosivo a frio e a quente em materiais cerâmicos à base de alumina, $\mathrm{PhD}$ thesis, PPGE3M, Federal University of Rio Grande do Sul, Porto Alegre, 2006.

[46] J. Vicenzi, Relação entre microestrutura e erosão (a frio e a quente) de revestimentos do sistema NiCr-Cr3C2 obtidos por aspersão térmica, $\mathrm{PhD}$ thesis, PPGE3M, Federal University of Rio Grande do Sul, Porto Alegre, 2007.

[47] J. He, J.M. Schoenung, Nanostructured coatings, Materials Science and Engineering: A, Vol. 336, iss. 1-2, pp. 274-319, 2002, doi: 10.1016/S09215093(01)01986-4

[48] M.A. Xueming, J.I. Gang, Nanostructured WC-Co alloy prepared by mechanical alloying, Journal of Alloys and Compounds, vol. 245, iss. 1-2, pp. L30L32, 1996, doi: 10.1016/S0925-8388(96)02678-3

[49] F.L. Zhang, C.Y. Wang, M. Zhu, Nanostructured WC/Co composite powder prepared by high energy ball milling, Scripta Materialia, vol. 49, iss. 11 , pp. 1123-1128, 2003, doi: 10.1016/j.scriptamat.2003.08.009

[50] J. Sun, F. Zhang, J. Shen, Characterizations of ball-milled nanocrystalline WC-Co composite powders and subsequently rapid hot pressing sintered cermets, Materials Letters, vol. 57, iss. 21, pp. 3140-3148, 2003, doi: 10.1016/S0167577X(03)00011-9

[51] M.I. Dvornik, A.V. Zaytsev, Research of surfaces and interfaces increasing during planetary ball milling of nanostructured tungsten carbide/cobalt powder, International Journal of Refractory Metals and Hard Materials, vol. 36, pp. 271-277, 2013, doi: 10.1016/j.ijrmhm.2012.10.004

[52] L.M. Berger, S. Saaro, T. Naumann, M. Wiener, V. Weihnacht, S. Thiele, J. Suchánek, Microstructure and properties of HVOF-sprayed chromium alloyed WC-Co and WC-Ni coatings, Surface and Coatings 
Technology, vol. 202, iss. 18, pp. 4417-4421, 2008, doi: 10.1016/j.surfcoat.2008.04.019

[53] I.M. Hutchings, A model for the erosion of metals by spherical particles at normal incidence, Wear, vol. 70, iss. 3, pp. 269-281, 1981, doi: 10.1016/0043-1648(81)90347-1

[54] I. Finnie, Some reflections on the past and future of erosion, Wear, vol. 186-187, pp. 1-10, 1995, doi: 10.1016/0043-1648(95)07188-1 